\title{
Stem cells and degenerative diseases
}

\author{
Antonio Carlos de Carvalho \\ From 5th Congress of the Brazilian Biotechnology Society (SBBIOTEC) \\ Florianópolis, Brazil. 10-14 November 2013
}

Cell therapies utilizing stem cells hold a great promise for the treatment of chronic-degenerative diseases. For more than a decade now, pre-clinical and clinical studies have been using bone marrow derived cells for therapy of diverse degenerative diseases. Cardiologists have unarguably performed the largest number of clinical trials and we will concentrate our presentation on the use of various cell therapies in heart diseases. The first wave of clinical trials using bone marrow derived mononuclear cells is close to an end and results are rather disappointing. Most controlled studies, using multicenter, double-blinded and placebo-controlled designs have not shown heart function improvement (based on measurements of ejection fraction - EF\% - as a surrogate endpoint). This has been observed for acute and chronic myocardial infarction [1-3], Chagasic cardiomyopathy [4] and more recently for dilated cardiomyopathy [unpublished results]. Clinical trials using mesenchymal stem cells, derived either from bone marrow or adipose tissue are underway [5]. These cells have been proofed safe but efficacy trials are still underway. Similarly, trials using cardiac derived stem/progenitor cells have been initiated with either c-kit positive [6] or cardiosphere derived cells [7]. Safety trials have been concluded and point to significant reduction in scar area in infarcted patients. Efficacy trials are currently starting. Pluripotent cells, either embryonic stem cells (ESC) or induced pluripotent stem cells (iPSC), have been tested in pre-clinical models of acute and chronic myocardial infarction with reported success [8], although permanent engraftment of these cells has been questioned. Finally, directed differentiation of fibroblasts into cardiomyocytes, using transcription factors, has been accomplished both in vitro and in vivo $[9,10]$, opening new therapeutic avenues for handling the epidemic of heart failure that has followed improved survival after myocardial infarction.
References

1. Traverse JH, Henry TD, Ellis SG, Pepine CJ, Willerson JT, Zhao DXM, et al: Effect of intracoronary delivery of autologous bone marrow mononuclear cells 2 to 3 weeks following acute myocardial infarction on left ventricular function: the LateTIME randomized trial. JAMA : the journal of the American Medical Association 2011, 306(19):2110-2119.

2. Traverse JH, Henry TD, Pepine CJ, Willerson JT, Zhao DXM, Ellis SG, et al: Effect of the use and timing of bone marrow mononuclear cell delivery on left ventricular function after acute myocardial infarction: the TIME randomized trial. JAMA : the journal of the American Medical Association 2012, 308(22):2380-2389.

3. Perin EC, Willerson JT, Pepine CJ, Henry TD, Ellis SG, Zhao DXM, et al: Effect of transendocardial delivery of autologous bone marrow mononuclear cells on functional capacity, left ventricular function, and perfusion in chronic heart failure: the FOCUS-CCTRN trial. JAMA : the journal of the American Medical Association 2012, 307(16):1717-1726.

4. Ribeiro-dos-Santos R, Rassi S, Feitosa G, Grecco OT, Rassi A, da Cunha AB, et al: Cell Therapy in Chagas Cardiomyopathy (Chagas Arm of the Multicenter Randomized Trial of Cell Therapy in Cardiopathies Study): A Multicenter Randomized Trial. Circulation 2012, 125(20):2454-2461.

5. Song K, Nam YJ, Luo X, Qi X, Tan W, Huang GN, et al: Heart repair by reprogramming non-myocytes with cardiac transcription factors. Nature 2012, 485(7400):599-604

6. Hare JM, Fishman JE, Gerstenblith G, DiFede Velazquez DL, Zambrano JP, Suncion VY, et al: Comparison of allogeneic vs autologous bone marrowderived mesenchymal stem cells delivered by transendocardial injection in patients with ischemic cardiomyopathy: the POSEIDON randomized trial. JAMA : the journal of the American Medical Association 2012, 308(22):2369-2379.

7. Bolli R, Chugh AR, D'Amario D, Loughran JH, Stoddard MF, Ikram S, et al: Cardiac stem cells in patients with ischaemic cardiomyopathy (SCIPIO): initial results of a randomised phase 1 trial. Lancet 2011 , 378(9806):1847-1857.

8. Makkar RR, Smith RR, Cheng K, Malliaras K, Thomson LE, Berman D, et al: Intracoronary cardiosphere-derived cells for heart regeneration after myocardial infarction (CADUCEUS): a prospective, randomised phase 1 trial. Lancet 2012.

9. Qiao H, Zhang H, Yamanaka S, Patel W, Petrenko NB, Huang B, et al: Long-term improvement in postinfarct left ventricular global and regional contractile function is mediated by embryonic stem cell-derived cardiomyocytes. Circulation: Cardiovascular Imaging 2011, 4(1):33-41.

10. leda M, Fu JD, Delgado-Olguin P, Vedantham V, Hayashi Y, Bruneau BG, Srivastava $D$ : Direct reprogramming of fibroblasts into functional cardiomyocytes by defined factors. Cell 2010, 142(3):375-386.

doi:10.1186/1753-6561-8-S4-019

Cite this article as: de Carvalho: Stem cells and degenerative diseases. BMC Proceedings 2014 8(Suppl 4):019. 